\title{
Earnings Quality and the Likelihood of Material Misstatement in the Financial Statements
}

\author{
John Trussel \\ University of Tennessee at Chattanooga
}

The purpose of this study is to identify financial indicators of poor earnings quality and to determine whether these indicators can distinguish firms with a high likelihood of material misstatement in their financial statements. Firms with significant accrual estimation errors are considered to have a high likelihood of material misstatement. A logistic regression model is developed using 10 financial indicators of poor earnings quality. Using a large sample across a 19 year period, the model is able to correctly classify up to $98 \%$ of firms as having either a high or a low likelihood of material misstatement.

Keywords: Earnings Quality, Material Misstatements, Accrual Estimation Errors, Detecting Fraud

\section{INTRODUCTION}

"I fear that we are witnessing an erosion in the quality of earnings, and therefore, the quality of financial reporting. Managing [earnings] may be giving way to manipulation; Integrity may be losing out to illusion."

-SEC Commissioner Arthur Levitt, September 28, 1998

The financial scandals of the early 2000s have raised serious questions about the quality of earnings of public-traded corporations and the potential for material misstatement including financial fraud. Earnings quality is a measure of the extent to which reported earnings reflect economic earnings. Poor earnings quality may result in a material misstatement, which is an inaccuracy in the reported financial statements, knowledge of which would affect a decision of a reasonable user of the statements (FASB, 2018). In a speech given in 1998, Arthur Levitt, then the chairman of the Securities and Exchange Commission (SEC), foresaw the major accounting scandals through a decline in earnings quality, resulting from "a game that, if not addressed soon, will have adverse consequences for America's financial reporting system" (Levitt, 1998). During that same speech, Levitt said that the SEC would specifically target companies using accounting practices that result in low earnings quality and a higher likelihood of material misstatement.

The primary purpose of this study is to identify financial indicators of poor earnings quality and to determine whether these indicators can distinguish firms with a high potential of material misstatement from firms with a low potential. Those interested in this model include investors, managers, board members, auditors, potential creditors, and regulators. In fact, under US auditing standards, an auditor "has a responsibility to plan and perform the audit to obtain reasonable assurance about whether the financial statements are free of material misstatement, whether caused by error or fraud" (AU 110, 
paragraph .02, AICPA, 1972). Also, auditors are required by AU Section 316 (AU-C Section 240) to assess the likelihood of fraud (AICPA, 2002, Loebbecke, et al. 1989).

The literature is replete with studies on earnings quality and earnings management (e.g., Dechow and Skinner, 2000, McNichols, 2000); however, few studies directly examine the relation between earnings quality and material misstatement. Dechow and Dechev (2002) (hereafter "DD") develop a model of earnings quality by focusing on accrual estimation errors determined by the effect of changes in working capital on past, present, and future cash flows. Several studies examine the issue of earnings management surrounding a particular event using an accruals-based model. The use of earnings management techniques, however, does not mean that a firm has a material misstatement. Beneish $(1997,1999)$ uses more direct measures of material misstatement by focusing on firms that are purported to have actually violated GAAP.

The focus of this paper is on the relation between financial indicators of poor earnings quality and the likelihood of material misstatement, particularly misstated earnings. I use public companies' data to compute financial indicators, which are intended to capture the financial environment that may lead to material misstatement. I empirically test the indicators using a sample of firms with significant accrual estimation errors using the DD model. The resultant model is used to determine the likelihood of material misstatement. This paper broadens the work of Beneish $(1997,1999)$ by extending the time period of study, expanding the nature of financial indicators, and testing the validity of the indicators against an earnings quality model. In the next section, I discuss the relationship among material misstatement, earnings management and earnings quality. Then, I develop financial indicators of poor earnings quality. The data and method utilized to test the model follow the development of these indicators. In the next-tolast section, the results of the empirical testing are discussed. A summary of the model and the testing concludes the paper in the last section.

\section{BACKGROUND ON EARNINGS QUALITY}

Three related but distinct concepts in the area of financial reporting are earnings quality, earnings management and material misstatement. Each is discussed in this section.

\section{Earnings Quality}

Earnings quality is a measure of the reliability of the reported earnings, typically defined as the extent to which reported earnings corresponds to economic (Hicksian) income (Schipper and Vincent, 2003). Since economic income is not readily measurable, the extant literature uses various constructs of earnings quality. Gaynor et al. (2016) define quality financial reports as those that are complete, neutral, and free from error and provide useful predictive or confirmatory information about the company's underlying economic position and performance. There are three earnings quality constructs derived from the timeseries properties of earnings--persistence, predictability and variability. Earnings quality is sometimes defined in terms of earnings persistence, which is the extent to which earnings are sustainable over time (e.g., Kormendi and Lipe, 1987; Collins and Kothari, 1989, Penman and Zhang, 2002). Earnings quality is also defined in terms of predictability, which is the ability of past earnings to predict future earnings (e.g., Lipe, 1990). Finally, earnings quality is also defined as income smoothing, which is the degree of the variability of earnings over time (e.g., Hand, 1989).

Another earnings quality construct is related to the implementation decisions regarding accounting and reporting. One view related to these implementation decisions is that earnings quality is inversely related to the amount of judgment, estimation and forecasting required of management in preparing financial reports (Schipper and Vincent, 2003). Under this view, earnings quality is impacted by both the amount of uncertainty in the firm's economic and structural factors that impact accrual estimates and the degree of managerial competence in making the accrual estimates.

Other earnings quality constructs focus on the changes in accruals, since there are many judgments and estimates rooted in accruals. Several studies address the relationship between earnings, accruals and cash flow realization of those accruals. For example, previous research demonstrates a contemporaneous 
relationship between accruals and current cash flows (McNichols et al., 1988; Dechow, 1994; Dechow, et al., 1998), and a relationship between accruals and future cash flows (Barth et al., 2001). Other studies address the normal versus abnormal accruals in an attempt to isolate accruals where management exercises discretion or manipulation in accounting techniques (i.e., discretionary accruals). For example, Jones (1991) explores whether or not firms manipulate their earnings surrounding import relief investigations. Also, Beatty, et al. (2002) study earnings manipulation by banks to avoid earnings declines. DD show that changes in working capital are a function of past, present and future cash flows. The present study uses the DD model of earnings quality in assessing the validity of the measures chosen as financial indicators of material misstatement.

\section{Earnings Management}

As stated above, one view related to accounting implementation decisions is that earnings quality is inversely related to the use of subversive judgments and estimates used by firms in financial reporting. This view is typically referred to as earnings management, defined as a case in which:

Managers use judgment in financial reporting and in structuring transactions to alter financial reports to either mislead some stakeholders about the underlying economic performance of the company or to influence contractual outcomes that depend on reported accounting numbers (Healy and Wahlen 1999, 268).

The annual financial statements send signals about a firm's future prospects, and management may be evaluated, in part, based on financial performance and condition. Thus, there may be incentive to manipulate the financial statements to send positive signals about the future prospects or to meet certain financial goals. However, these manipulations may or may not result in a material misstatement in the financial statements. There is a material misstatement only if the manipulation results in a material violation of GAAP, as discussed below.

Beneish (1997) and Dechow et al. (1995) suggest that earnings management is related to financial condition. Both studies find a correlation between financial condition and earnings management. That is, those in relatively poor financial condition are more likely to manipulate their accounting records. In their review of the literature, Healy and Wahlen (1999) note that there is evidence to support several incentives for earnings management. For example, the research documents that firms manage earnings to enhance their financial statements prior to public offerings, to increase executive compensation, to provide job security, to avoid violating debt covenants, and to reduce regulatory costs. Also, some firms manage their earnings to be conservative in their reporting methods. Ruch and Taylor (2015) summarize the research on how accounting conservatism impacts earnings quality.

\section{Material Misstatement}

A material misstatement is defined as an inaccuracy in the reported financial statements, knowledge of which would affect a decision of a reasonable user of the financial statements (FASB, 2018). A material misstatement is a result of not following generally accepted accounting principles (GAAP). Such a misstatement may be made intentionally or unintentionally by the firm's management. Intentional material misstatement is considered fraudulent financial reporting (AICPA, 2002). Unintentional material misstatement (also called "error") may be due factors such as the inexperience of management and the amount of required accounting estimates (Schipper and Vincent 2003).

According to AU Section 316 (AU-C Section 240) (AICPA, 2002), fraud is an intentional act that results in a material misstatement in financial statements. This AU section focuses on two types of fraud-fraudulent financial reporting and misappropriation of assets. Fraudulent financial reporting may involve acts such as the following:

- Manipulation, falsification, or alteration of accounting records or supporting documents from which the financial statements are prepared.

- Misrepresentation in, or intentional omission from, the financial statements of events, transactions, or other significant information. 
- Intentional misapplication of accounting principles relating to amounts, classification, manner of presentation, or disclosures (AICPA, 2002).

In essence, fraudulent financial reporting is the management of earnings to the extent that violates GAAP. Also, if there is a violation of GAAP, then there the earnings quality is considered to be poor. However, a material misstatement may also be due to unintentional errors, such as lack of expertise in estimating accruals (e.g., estimating the allowance for doubtful accounts).

Figure 1 summarizes the relationship between earnings quality and GAAP and between earnings management and GAAP. The vertical line represents the threshold for following GAAP. The area to the right of the line represents the use of accounting practices that follow GAAP, resulting in no material misstatement. The area to the left represents the use of accounting practices that violate GAAP, resulting in a material misstatement. The use of earnings management to the extent that GAAP is violated results in poor earnings quality and is considered fraud or error. Fraud is an intentional, material misstatement. Error is an unintentional, material misstatement, (e.g., due to lack of expertise).

FIGURE 1

EARNINGS QUALITY, EARNINGS MANAGEMENT AND MATERIAL MISSTATEMENT

\begin{tabular}{lll} 
Poor & \multicolumn{2}{c}{ Level of Earnings Quality } \\
Violation of GAAP & & \\
Material misstatement (fraud or error) & Level of Earnings Management & \\
\hline Max. & Nollowing GAAP & \\
\hline
\end{tabular}

Much of the previous research defines earnings management in terms of discretionary accruals (Jones, 1991, Dechow et al., 1995). These studies attempt to isolate discretionary accruals from total accruals using a variety of methods (e.g., Healy 1985, DeAngelo, 1986, and Jones, 1991). Other studies have questioned the ability of these models to identify earnings management. For example, Guay et al. (1996) find that these accrual models estimate discretionary accruals with considerable imprecision. Beneish (1997, 1999) develops models for detecting earnings management using more direct measures. He suggests that the financial condition of an organization is reflected in particular financial variables, such as sales growth and profit margins, and that these variables are associated with earnings management. Using a sample of firms purported to have managed their earnings, he finds a significant relationship between the financial variables and earnings management.

I extend Beneish's (1997) model in three important ways. First, I extend the time period to include financial reports issued during 1999-2017, which includes a time of enhanced SEC investigations into earnings manipulation practices. Second, I select financial variables based on those areas identified by the SEC as critical to analysis of earnings management. Third, I test the reasonableness of these financial variables using the DD model of earnings quality.

\section{MODEL DEVELOPMENT}

I develop a model of potential material misstatement based on constructs derived from implementation decisions, as discussed in the previous section. Using the perspective of implementation decisions, earnings quality is inversely related to the use of subversive judgments and estimates in the 
financial reporting process. In such case, poor earnings quality may result in material misstatement. In this section, I develop indicators of poor earnings quality, which, as discussed in the previous section, are also indicators of potential material misstatement due to the relationship between poor earnings quality and the potential for material misstatement (see Figure 1). The indicators attempt to capture accounts that are subject to significant estimates and judgments. I also discuss a model of earnings quality that I use to test the reasonableness of the chosen financial indicators.

\section{Indicators of Poor Earnings Quality and Potential Material Misstatement}

In his speech on earnings management, Arthur Levitt (1998), then the chairman of the SEC, identified five techniques that companies employ to manipulate their earnings - "cookie jar" reserves, "big bath" charges, creative acquisition accounting, improper revenue recognition techniques, and immaterial violations of GAAP. I use these five areas to develop indicators of poor earnings quality and potential material misstatement, since the SEC began to specifically search for such manipulation techniques. Levitt (1998) said:

The SEC's review and enforcement teams will reinforce these regulatory initiatives. We will formally target reviews of public companies that announce restructuring liability reserves, major write-offs or other practices that appear to manage earnings. Likewise, our enforcement team will continue to root out and aggressively act on abuses of the financial reporting process (p. 7).

It is interesting to note that the some of the most well-known cases of earnings management and fraud, such as Enron, Global Crossing and WorldCom, were discovered just a few years following this speech.

\section{Cookie Jar Reserves}

Accounting is subject to numerous estimates, such as estimated warranty claims, that are highly subjective in nature and give rise to manipulation. If managers use unrealistic assumptions to develop these estimates, then the estimates may be significantly misstated. Mangers have incentives to overstate certain estimated liabilities, which would reduce reported earnings, during a period when they are experiencing extremely positive operating results. In periods of marginal operating performance, firms could simply reverse the reserves, which would increase reported earnings. Two measures of the use of such reserves are ALLOW and OTHLIAB. ALLOW, allowance for bad debts as a percentage of total accounts receivable, is a measure of the percentage of accounts receivable that are estimated to be uncollectible. OTHLIAB, other liabilities as percentage of total assets, measures the percentage of the total capital structure that typically represent estimated liabilities. Managers creating cookie jar reserves will overstate these accounts. Thus, I predict that these ratios are directly related to the likelihood of material misstatement, which increases the potential for material misstatement.

\section{Big Bath Charges}

Big bath charges are non-operating expenses, such as restructuring charges, which may be used to mask a current or future operating loss. Research (e.g., Anabila, 2012) indicates that investors tend to overlook non-operating charges as nonrecurring and focus more on the recurring results from operations. Thus, managers have an incentive to report operating profits by classifying certain losses as non-operating. For example, a manager may report current and estimated future expenses as a current period restructuring (non-operating) charge rather than a current or future period operating expense. A measure of big bath charges is NONOPER, non-operating income (loss) as a percentage of sales. Non-operating income or loss includes items such as restructuring charges and discontinued operations. I predict an inverse relationship between NONOPER and poor earnings quality; thus, lower values of NONOPER are predicted to lead to a higher likelihood of material misstatement. If a manager shifts a current or future period operating expense to non-operating in the current period, then the lower (more negative) non-operating results in better outcomes from operating activities. 


\section{Creative Acquisition Accounting}

When using the purchase or the acquisition methods of accounting, the acquiring firm allocates the excess of the purchase price over the fair value of the acquired firm's net tangible assets to identifiable intangible assets with the residual classified as goodwill. Current accounting rules allow for the write down of long-lived assets and goodwill that have become permanently impaired. That is, if the value of an asset declines and this decline is deemed permanent, then the firm must recognize an impairment loss. The more that is allocated to goodwill and other intangible assets during an acquisition, the more the company may expense (as an impairment loss) in the future as needed, similar to a cookie jar reserve. I use ACQUIRE, as a measure of the amount of acquisitions during the year. The ratio is acquisitions as a percentage of total assets, and is predicted to be directly related to poor earnings quality (and thus more potential for material misstatement).

\section{Improper Revenue and/or Expense Recognition}

Levitt (1998) included improper revenue recognition as an earnings management technique. In order to overstate revenues and thus earnings, managers may recognize revenues in a period before allowed by GAAP. For example, a firm may improperly recognize revenue prior to completion and delivery of the product or service. The growth in sales is likely to be higher than otherwise if fictitious revenues are recorded or if revenues are recognized in advance. GROWTH is the percentage change in sales from the previous year and has a predicted positive sign with poor earnings quality and the potential for material misstatement.

Improper expense recognition is a corollary to improper revenue recognition. A firm may improperly postpone the recognition of expenses to a future period in order to enhance current period earnings. I use several proxies for improper expense recognition. A manager may improve his or her earnings by improperly capitalizing expenses by postponing expense recognition. OTHASSETS, other assets as a percent of total assets, is predicted to have a positive sign, indicating postponement of expense recognition by overstating other assets, such as deferred charges. The rate at which a firm depreciates its fixed assets, DEPRATE, is predicted to be negatively related to the potential for material misstatement. A lower depreciation rate increases earnings. A company may also improperly capitalize rather than expense research and development costs. RESEARCH, measured as research and development costs to total revenues, is thus predicted to have a negative relationship with the likelihood of material misstatement.

\section{Immaterial Violations of GAAP}

Research has shown that capital markets react to earnings surprises (e.g., Pinello 2008); thus, managers have incentive to meet or exceed analysts' expectations of earnings or previous year's earnings. If the actual EPS is only slightly below the forecasts or previous year's EPS, then managers may improperly adjust revenues or expenses, while claiming that such adjustments are immaterial since they on a per-share basis. Managers desire to show growth in earnings is reflected in an increase in EPS. The change in earnings per share, EPSCHG, is the year-over-year change in the basic EPS and has a predicted positive sign with potential material misstatement.

The indicators of poor earnings quality and potential material misstatement are summarized in Table 1. I also include size as a control variable. SIZE is measured as the natural log of total assets. 
TABLE 1

INDICATORS OF MATERIAL MISSTATEMENT

\begin{tabular}{|c|c|c|c|}
\hline Category & Variable & Measurement & $\begin{array}{l}\text { Predicted } \\
\text { Sign }\end{array}$ \\
\hline Cookie Jar Reserve & ALLOW & $\begin{array}{c}\text { Allowance for bad debts [recd] } \\
\text { Accounts Receivable, Gross [rect] }\end{array}$ & + \\
\hline Cookie Jar Reserve & OTHERLIAB & $\frac{\text { Other Liabilities [lo] }}{\text { Total Assets [at] }}$ & + \\
\hline Big Bath Charges & NONOPER & $\frac{\text { Non-Operating Income [nopi] }}{\text { Sales [sale] }}$ & - \\
\hline $\begin{array}{l}\text { Creative Acquisition } \\
\text { Accounting }\end{array}$ & ACQUIRE & $\frac{\text { Acquisitions [aqc] }}{\text { Total Assets [at] }}$ & + \\
\hline $\begin{array}{l}\text { Improper Recognition } \\
\text { Techniques }\end{array}$ & GROWTH & $\frac{\Delta \text { Sales }[\Delta \text { sale }]}{\text { Sales }_{\mathrm{t}-1}}$ & + \\
\hline $\begin{array}{l}\text { Improper Recognition } \\
\text { Techniques }\end{array}$ & OTHASSET & $\frac{\text { Other Assets [ao] }}{\text { Total Assets [at] }}$ & + \\
\hline $\begin{array}{l}\text { Improper Recognition } \\
\text { Techniques }\end{array}$ & DEPRATE & $\begin{array}{c}\text { Depreciation Expense [dp] } \\
\text { Property, Plant \& Equipment [ppegt] }\end{array}$ & - \\
\hline $\begin{array}{l}\text { Improper Recognition } \\
\text { Techniques }\end{array}$ & RESEARCH & $\frac{\text { Research \& Development [xrd] }}{\text { Sales [sale] }}$ & - \\
\hline $\begin{array}{l}\text { Immaterial Violations of } \\
\text { GAAP }\end{array}$ & EPSCHG & $\frac{\Delta \text { EPS Basic }[\Delta \text { epspi] }}{\text { EPS Basic }_{t-1}}$ & + \\
\hline Control & SIZE & $\ln$ (Total Assets) [at] & $?$ \\
\hline
\end{tabular}

Note: Letters in brackets represent Compustat data codes.

\section{The DD Accrual Estimation Errors Model of Earnings Quality}

As stated in section II, if a firm makes a material misstatement, then by definition it has poor earnings quality (see Figure 1). To determine if the indicators in Table 1 are related to earnings quality, I use accrual estimation errors as a proxy for earnings quality. Specifically, I employ the model of accrual estimation errors developed by DD, who posit that higher accrual estimation errors represent lower earnings quality. Accruals are temporary adjustments of cash flows that transfer the recognition of cash flows to other periods. These transfers allow for a better reflection of true financial performance at the expense of estimates of future cash flows. These estimates result in corrections in future periods. Therefore, "the quality of accruals and earnings is decreasing in the magnitude of accrual estimation errors" (Dechow and Dichev, 2002, 1). DD posit that earnings are an adjustment of past, present, and future cash flows, including an adjustment for estimates and corrections of errors in estimates. The empirical version of their accruals estimation model is:

$\Delta \mathrm{WC}=\mathrm{b}_{0}+\mathrm{b}_{1} \mathrm{CFO}_{\mathrm{t}-1}+\mathrm{b}_{2} \mathrm{CFO}_{\mathrm{t}}+\mathrm{b}_{3} \mathrm{CFO}_{\mathrm{t}+1}+\varepsilon_{\mathrm{t}}$

where $\triangle \mathrm{WC}$ is change in working capital, a proxy for accruals, CFO is cash flows from operations, a proxy for cash flows related to accruals and $\varepsilon$, the residual, is the accruals estimation error. DD define a change in working capital as the change in accounts receivable, plus the change in inventory, plus the change in other assets, less the change in accounts payable, less the change in taxes payable. I use this definition in the present study, too. They hypothesize $b_{2}$ is negative, while $b_{1}$ and $b_{3}$ are positive. Earnings and the accrual portion of earnings represent shifts of current cash flows to future periods and thus are negatively related to cash flows in the present year. Also, earnings and the accrual portion of earnings anticipate future cash flow and correct for estimates in prior years; thus, they are positively related to past 
and future cash flows. DD suggest using the standard deviation of the residual in equation (1) as a measure of earnings quality, with higher accruals estimations errors representing lower earnings quality. I use their model to determine if the indicators of material misstatement in Table 1 are related to earnings quality.

\section{EMPIRICAL STUDY}

The empirical testing proceeds in two stages. First, I test whether or not the indicators of potential material misstatement from Table 1 are related to the DD accruals estimation model of earnings quality. Second, I test whether or not these indicators can distinguish between firms that have significant accruals estimation errors from those that do not. Significant accruals estimation errors are used as a proxy for poor earnings quality and potential material misstatement.

\section{Tests of the Indicators of Material Misstatement on the DD Accruals Estimation Model}

I use the DD model (1) of accrual estimation errors to test the indicators of potential material misstatement from Table 1. DD use three versions of their model; namely, firm-specific regressions, industry-wide regressions and pooled regression. As previously discussed, DD define the quality of accruals to be the standardized residual from the regression equation (1) based on the firm-specific regressions. I modify their pooled regression tests of their model by using a cross-sectional, time series (panel data) approach, while adjusting for autocorrelation.

For the sample, I use annual report data from 1999 to 2017 from the Compustat annual industrial files. I chose this period since the SEC began to focus its attention on certain aspects of financial reporting following the chairman's speech (Levitt, 1998). These aspects of financial reporting drive the development of indicators summarized in Table 1. Following DD, I truncate the most extreme one percent of cash flows from operations (CFO) and changes in working capital and limit the study to firms with data available for each of the variables. These restrictions result in a sample of 91,547 firm-year observations. The sample selection criteria are summarized in Table 2.

TABLE 2

\section{COMPOSITION OF SAMPLE}

Panel A: Sample for tests of earnings quality

\begin{tabular}{|l|r|r|}
\hline & Firm-years & Percent \\
\hline Firm-years from 1999-2017 on Compustat Industrial & 181,785 & 100.0 \\
\hline Cash flow or working capital data not available & 82,428 & 45.3 \\
\hline Outliers & $\mathbf{7 , 8 1 0}$ & $\underline{4}$ \\
\hline Final sample for accrual estimation tests & 91,547 & 50.4 \\
\hline Material misstatement variables not available & $\underline{78,179}$ & $\underline{43.0}$ \\
\hline Final sample for material misstatement tests & 13,368 & 7.4 \\
\hline
\end{tabular}

Panel B: Sample for tests of material misstatement

\begin{tabular}{|l|r|r|}
\hline By Status $^{\mathrm{b}}$ & Firm-years & Percent \\
\hline High likelihood of material misstatement & 778 & 5.8 \\
\hline Low likelihood of material misstatement & $\underline{12,590}$ & $\underline{94.2}$ \\
\hline Final sample for material misstatement tests & 13,368 & 100.0 \\
\hline
\end{tabular}

${ }^{a}$ Following DD, firms with cash flows from operations in the top or bottom one percentile were eliminated as outliers.

${ }^{\mathrm{b}}$ Following, Trussel (2003), a firm is defined having a high likelihood of material misstatement if its accrual estimation errors are significantly greater than zero at the 5\% (two-tailed) level during the period 1999 to 2017 . The accrual estimation errors are the standardized residuals from the DD model (1). 
Table 3 presents the results of the accrual estimations model (1), which is similar to the pooled regressions testing of the DD model. My testing confirms their results. Overall, the model is significant, the current cash flows are negatively related to changes in working capital, and the past and future cash flows are positively related to changes in working capital, as hypothesized. The adjusted $\mathrm{R}^{2}$ of 0.01 is well below their results of 0.29 . This may be due to my relaxing the restriction that firms have at least eight years of data to be included in the study, and I use cross-sectional, time series approach adjusted for autocorrelation.

TABLE 3

\section{ACCRUALS ESTIMATIONS REGRESSION MODEL ${ }^{\mathrm{a}}$}

$\Delta \mathrm{WC}=\mathrm{b}_{0}+\mathrm{b}_{1} \mathrm{CFO}_{\mathrm{t}-1}+\mathrm{b}_{2} \mathrm{CFO}_{\mathrm{t}}+\mathrm{b}_{3} \mathrm{CFO}_{\mathrm{t}+1}+\varepsilon_{\mathrm{t}}$

\begin{tabular}{|l|l|l|l|l|}
\hline Variable $^{\mathrm{b}}$ & Predicted Sign & Coefficient & $\mathrm{t}$ & $\mathrm{p}^{-\mathrm{value}^{\mathrm{c}}}$ \\
\hline $\mathrm{INTERCEPT}^{\mathrm{C}}$ & & 0.023 & 4.884 & $<0.001$ \\
\hline $\mathrm{CFO}_{\mathrm{t}-1}$ & + & 0.260 & 19.681 & $<0.001$ \\
\hline $\mathrm{CFO}_{\mathrm{t}}$ & - & -0.408 & -28.378 & $<0.001$ \\
\hline $\mathrm{CFO}_{\mathrm{t}+1}$ & + & 0.080 & 6.045 & $<0.001$ \\
\hline \multicolumn{2}{|l|}{ Model F $=258.347$ (p-value $<0.001$, two-tailed test). Adjusted R ${ }^{2}=0.01$} & \\
\hline
\end{tabular}

${ }^{\mathrm{a}}$ The OLS regression model is estimated using a sample of 91,547 firms

${ }^{\mathrm{b}}$ The dependent variable is the year-over-year change in working capital. CFO is the cash flows from operations.

${ }^{c}$ All p-values on coefficients are based on one-tailed t-tests, with the exception of the intercept, which is based on a two-tailed t-test.

The absolute value of standardized residuals from the regression model (1) above are used as a proxy for earnings quality $\left(E Q_{t}\right)$ :

$$
E Q_{t}=\left|\frac{\varepsilon}{\sigma}\right|
$$

where higher amounts represent higher accrual estimation errors, lower earnings quality and a higher potential for earnings misstatement. To test whether or not the indicators of material misstatement, summarized in Table 1, are related to earnings quality, I use the following regression:

$E Q_{t}=\mathrm{b}_{0}+\mathrm{b}_{1}$ ALLOW $_{\mathrm{t}}+\mathrm{b}_{2}$ OTHERLIAB $_{\mathrm{t}}+\mathrm{b}_{3}$ NONOPER $_{\mathrm{t}}+\mathrm{b}_{4}$ AQUIRE $_{\mathrm{t}}+\mathrm{b}_{5}$ GROWTH $_{\mathrm{t}}+\mathrm{b}_{6}$ OTHASSET $_{\mathrm{t}}+\mathrm{b}_{7}$ DEPRATE $_{\mathrm{t}}+\mathrm{b}_{8}$ RESEARCH $_{\mathrm{t}}+\mathrm{b}_{9} \mathrm{EPSCHG}_{\mathrm{t}}+\mathrm{b}_{10} \mathrm{SIZE}_{\mathrm{t}}+\varepsilon_{\mathrm{t}}$

$E Q_{t}$ is the proxy for earnings quality, defined above, and the independent variables are the indicators of material misstatement summarized in Table 1.

Table 4 includes the correlation coefficients between each pair of independent variables and the dependent variable, EQ. The Pearson correlation coefficients are very small between each pair of independent variables. Although some of the correlations between the independent variables are significant, there is no cause for concern with multicollinearity. All of the independent variables are significantly and positively correlated with EQ, except for size (which is negatively correlated with EQ) and NONOPER (which is not significantly correlated with EQ). The significant and positive correlations between both EQ and DEPRATE and EQ and RESEARCH were not anticipated. They were hypothesized to have a significant and negative correlation with EQ. 
TABLE 4

PEARSON CORRELATION COEFFICIENTS ${ }^{\mathrm{a}}$

\begin{tabular}{|l|l|l|l|l|l|l|l|l|l|l|}
\hline Variable & EQ & 1 & 2 & 3 & 4 & 5 & 6 & 7 & 8 & 9 \\
\hline 1. ALLOW & $0.083^{* *}$ & & & & & & & & & \\
\hline 2. OTHERLIAB & $0.018^{* *}$ & 0.003 & & & & & & & & \\
\hline 3. NONOPER & -0.012 & 0.003 & $-0.021^{* *}$ & & & & & & & \\
\hline 4. ACQUIRE & $0.116^{* *}$ & 0.001 & -0.001 & 0.005 & & & & & & \\
\hline 5. GROWTH & $0.019^{* *}$ & 0 & 0 & 0 & $-0.026^{* *}$ & & & & & \\
\hline 6. OTHASSET & $0.133^{* *}$ & 0.005 & 0.003 & $-0.042^{* *}$ & 0.008 & 0.005 & & & & \\
\hline 7. DEPRATE & $0.048^{* *}$ & 0.001 & 0 & 0 & 0.005 & 0 & 0.003 & & & \\
\hline 8. RESEARCH & $0.089^{* *}$ & $0.030^{* *}$ & 0.012 & $0.105^{* *}$ & 0.002 & 0 & -0.002 & 0.007 & & \\
\hline 9. EPSCHG & $0.014^{*}$ & 0 & $0.027^{* *}$ & -0.004 & $-0.021^{* *}$ & 0 & $-0.020^{* *}$ & 0.004 & 0.007 & \\
\hline 10. SIZE & $-0.273^{* *}$ & $-0.066^{* *}$ & $-0.020^{* *}$ & $0.020^{* *}$ & $0.018^{* *}$ & $-.015^{*}$ & 0.004 & $-0.035^{* *}$ & $-0.038^{* *}$ & -0.003 \\
\hline
\end{tabular}

${ }^{\mathrm{a}}$ See Table 1 for a description of the variables, except for EQ, which is the absolute value of the standardized residuals from the accruals estimation model (1).

* Significance at the 0.05 level (two-tailed)

** Significance at the 0.01 level (two-tailed)

Table 5 includes the results of the regression (2) of the indicators of material misstatement on earnings quality. The model is significant overall, indicating that the combined indicators are significantly related to earnings quality. As predicted, ALLOW, OTHERLIAB, ACQUIRE, GROWTH, OTHASSET, and EPSCHG are significant at the 0.05 level with the hypothesized positive signs. SIZE is significant and inversely related to EQ. However, NONOPER, DEPRATE, and RESEARCH, although significant, do not have the predicted negative signs. Although not all of the signs on the indicators are as predicted, each is significant in this earnings quality model. The modelled indicators of potential material misstatement are indeed related to earnings quality. Thus, the independent variables are reasonable indicators of earnings quality. 
TABLE 5

THE RESIDUALS REGRESSION MODEL WITH THE INDICATORS OF MATERIAL MISSTATEMENT ${ }^{\mathrm{a}, \mathrm{b}}$

$\mathrm{EQ}_{\mathrm{t}}=\mathrm{b}_{0}+\mathrm{b}_{1}$ ALLOW $_{\mathrm{t}}+\mathrm{b}_{2}$ OTHERLIAB $_{\mathrm{t}}+\mathrm{b}_{3}$ NONOPER $_{\mathrm{t}}+\mathrm{b}_{4}$ AQUIRE $_{\mathrm{t}}+\mathrm{b}_{5}$ GROWTH $_{\mathrm{t}}+\mathrm{b}_{6}$ OTHASSET $_{t}+b_{7}$ DEPRATE $_{t}+b_{8}$ RESEARCH $_{t}+b_{9}$ EPSCHG $_{t}+b_{10}$ SIZE $_{t}+\varepsilon_{t}$

\begin{tabular}{|c|c|c|c|c|}
\hline Variable $^{\mathrm{d}}$ & Predicted & Coefficient & Std. Error & $\mathrm{p}$-value $\mathrm{e}^{\mathrm{c}}$ \\
\hline Constant & & 0.634 & 0.021 & $<0.001$ \\
\hline ALLOW & + & 1.167 & 0.056 & $<0.001$ \\
\hline OTHLIAB & + & 1.349 & 0.100 & $<0.001$ \\
\hline NONOPER & - & 0.004 & 0.001 & $<0.001$ \\
\hline ACQUIRE & + & 9.410 & 0.467 & $<0.001$ \\
\hline GROWTH & + & 0.001 & 0.000 & $<0.001$ \\
\hline OTHASSET & + & 2.364 & 0.204 & $<0.001$ \\
\hline DEPRATE & - & 0.227 & 0.015 & $<0.001$ \\
\hline RESEARCH & - & 0.006 & 0.001 & $<0.001$ \\
\hline EPSCHG & + & 0.021 & 0.004 & $<0.001$ \\
\hline SIZE & $?$ & -0.091 & 0.003 & $<0.001$ \\
\hline
\end{tabular}

${ }^{\mathrm{a}}$ The OLS regression model is estimated using a sample of 13,368 firm-years.

${ }^{\mathrm{b}}$ The dependent variable, earnings quality, is proxied as the absolute value of the standardized residual from the DD accruals estimation model (1).

${ }^{c}$ All p-values on coefficients are based on one-tailed t-tests, except for the intercept, which is based on a two-tailed t-test.

${ }^{\mathrm{d}}$ The independent variables are defined in Table 1.

\section{The Likelihood of Material Misstatement}

The results of the tests on model (2) provide support for the 10 indicators of material misstatement from Table 1. I use these indicators to detect whether or not they can distinguish between firms that have a high likelihood of material misstatement from those that have a low likelihood. Firms with significant accrual estimation errors from the DD model (1) are assumed to have a high likelihood of material misstatement. Following Trussel (2003), a firm is defined having a high likelihood of material misstatement if its accruals estimation error [the standardized residual from the DD model (1) above] is significantly different from zero at the five-percent (two-tailed) level during the period 1999 to 2017. By definition, the standardized residual has a mean of zero and a standard deviation of one. If the standardized residual is greater than (less than) two (negative two), then the standardized residual is significantly different than zero at the five-percent level. Applying these criteria results in 778 firms with significant accrual estimation errors (and thus a high likelihood of material misstatement) and 12,590 other firms that do not have significant accruals estimation errors (and thus a low likelihood of material misstatement).

\section{Univariate Tests of the Indicators of Material Misstatement}

Descriptive statistics for the two categories of firms are included in Table 6. Those with significant accruals estimation errors (i.e., those with a high likelihood of material misstatement) are coded 1, and those with accruals estimations errors not significantly different from zero (i.e., those with a low likelihood of material misstatement) are coded 0 . The results are similar to previous findings in this study. Firms with a high likelihood of material misstatement have significantly higher values for every indicator, except NONOPER and SIZE. Firms with a high likelihood of material misstatement are significantly smaller (SIZE) than the low likelihood firms, while there is no significant difference in non-operating 
income (NONOPER). Similar to the previous results, it was not anticipated that firms with a high likelihood of material misstatement would have significantly higher depreciate rates (DEPRATE) and R\&D expenditures (RESEARCH).

TABLE 6

DESCRIPTIVE STATISTICS FOR THE INDICATORS OF MATERIAL MISSTATEMENT ${ }^{\mathrm{a}}$

\begin{tabular}{|c|c|c|c|c|c|}
\hline Variable & STATUS $^{b}$ & Mean & Std. Dev. & $\mathrm{t}$ & Sig. \\
\hline \multirow[t]{2}{*}{ ALLOW } & 0 & 0.033 & 0.030 & -12.330 & $<0.001$ \\
\hline & 1 & 0.260 & 2.064 & & \\
\hline \multirow[t]{2}{*}{ OTHLIAB } & 0 & 0.039 & 0.043 & -2.947 & 0.003 \\
\hline & 1 & 0.181 & 5.394 & & \\
\hline \multirow[t]{2}{*}{ NONOPER } & 0 & 0.005 & 0.009 & 1.392 & 0.164 \\
\hline & 1 & -0.929 & 75.320 & & \\
\hline \multirow[t]{2}{*}{ ACQUIRE } & 0 & 0.002 & 0.005 & -16.327 & $<0.001$ \\
\hline & 1 & 0.014 & 0.084 & & \\
\hline \multirow[t]{2}{*}{ GROWTH } & 0 & 0.075 & 0.181 & -3.523 & $<0.001$ \\
\hline & 1 & 8.898 & 281.039 & & \\
\hline \multirow[t]{2}{*}{ OTHASSET } & 0 & 0.033 & 0.031 & -20.210 & $<0.001$ \\
\hline & 1 & 0.056 & 0.117 & & \\
\hline \multirow[t]{2}{*}{ DEPRATE } & 0 & 0.108 & 0.065 & -7.623 & $<0.001$ \\
\hline & 1 & 0.584 & 7.006 & & \\
\hline \multirow[t]{2}{*}{ RESEARCH } & 0 & 0.064 & 0.080 & -13.709 & $<0.001$ \\
\hline & 1 & 18.889 & 154.107 & & \\
\hline \multirow[t]{2}{*}{ EPSCHG } & 0 & -0.182 & 0.794 & -2.420 & 0.016 \\
\hline & 1 & 0.194 & 17.370 & & \\
\hline \multirow[t]{2}{*}{ SIZE } & 0 & 5.858 & 2.416 & 39.023 & $<0.001$ \\
\hline & 1 & 4.007 & 3.077 & & \\
\hline
\end{tabular}

${ }^{a}$ See Table 1 for a description of the variables.

${ }^{\mathrm{b}}$ A firm is coded 1, with a high likelihood material misstatement, if its accrual estimation errors are significantly greater than zero at the 5\% (two-tailed) level during the period 1999 to 2017. The accrual estimation errors are based on the DD model. A firm is coded 0, otherwise, with a low likelihood of material misstatement.

\section{Multivariate Tests of the Likelihood of Material Misstatement}

I develop and test a model of the likelihood of material misstatement using a similar methodology used by Beneish (1999). The underlying latent dependent variable is the probability of material misstatement for firm $i$. This probability is related to the observed variable, Status $i$, through the relation:

Status $_{i}=1$, if the firm has significant accruals estimations errors, and Status $_{i}=0$, otherwise.

Logistic regression using all the indicators of material misstatement predicts the probability of material misstatement for the $k^{\text {th }}$ status for firm $i$ as $P\left(\right.$ Status $\left._{i k}\right)$ and is calculated as:

$P\left(\right.$ Status $\left._{i k}\right)=\frac{1}{1+e^{-Z}}$

where: 
$\mathrm{Z}_{\mathrm{i}}=\mathrm{b}_{0}+\mathrm{b}_{1}$ ALLOW $_{\mathrm{t}}+\mathrm{b}_{2}$ OTHERLIAB $_{\mathrm{t}}+\mathrm{b}_{3}$ NONOPER $_{\mathrm{t}}+\mathrm{b}_{4}$ AQUIRE $_{\mathrm{t}}+\mathrm{b}_{5}$ GROWTH $_{\mathrm{t}}+\mathrm{b}_{6}$ OTHASSET $_{\mathrm{t}}+\mathrm{b}_{7}$ DEPRATE $_{\mathrm{t}}+\mathrm{b}_{8}$ RESEARCH $_{\mathrm{t}}+\mathrm{b}_{9}$ EPSCHG $_{\mathrm{t}}+\mathrm{b}_{10} \mathrm{SIZE}_{\mathrm{t}}+\varepsilon_{\mathrm{t}}$

The estimation sample consisting of half the data set (used to develop the model) is randomly selected, and the other half of the data set (the holdout sample) is used to test the model. The results of the logistic regression model are shown in Table 7.

Overall, the model is significant, as indicated by the model Chi-square, and all of the independent variables are significant (at less than the 0.01 level). Also, the model $\mathrm{R}^{2}$ is fairly high at 0.631 . All of the variables are statistically significant with the predicted signs, except for DEPRATE, RESEARCH, EPSCHG. Compared with other firms, firms with significant accruals estimation errors were expected to have lower depreciation rates, spend less on research and development costs and have larger changes in basic earnings-per-share. However, this was not the case. These firms have higher depreciated rates and R\&D costs and smaller changes in EPS than their counterparts.

TABLE 7

THE LOGIT MODEL OF THE LIKELIHOOD OF MATERIAL MISSTATEMENT ${ }^{\mathrm{a}}$

\begin{tabular}{|c|c|c|c|c|}
\hline Variable $^{b}$ & Predicted & Coefficient & Standard Error & p-value ${ }^{c}$ \\
\hline Constant & & -4.947 & 0.276 & 0.000 \\
\hline ALLOW & + & 15.630 & 1.633 & 0.000 \\
\hline OTHLIAB & + & 4.619 & 1.493 & 0.002 \\
\hline NONOPER & - & 1.216 & 0.106 & 0.000 \\
\hline ACQUIRE & + & 45.306 & 9.494 & 0.000 \\
\hline GROWTH & + & 1.807 & 0.242 & 0.000 \\
\hline OTHASSET & + & 7.557 & 1.763 & 0.000 \\
\hline DEPRATE & - & 4.468 & 0.747 & 0.000 \\
\hline RESEARCH & - & 6.281 & 0.548 & 0.000 \\
\hline EPSCHG & + & -0.039 & 0.016 & 0.015 \\
\hline SIZE & $?$ & -0.247 & 0.038 & 0.000 \\
\hline \multicolumn{5}{|c|}{ Model Chi-square $=1,784.502(\mathrm{p}$-value $=<0.001$, two-tailed test $)$} \\
\hline \multicolumn{5}{|c|}{ Nagelkerke $\mathrm{R}^{2}=0.631$} \\
\hline \multicolumn{5}{|c|}{$\begin{array}{l}\text { a The logistic regression model is estimated using a sample of } 417 \text { firms with a high likelihood of material } \\
\text { misstatement and } 6,173 \text { firms with a low likelihood. } \\
\text { b The latent dependent variable (probability of material misstatement) equals one if the firm has significant accruals } \\
\text { estimation errors (i.e, the proxy for potential material misstatement) and zero, otherwise. The independent variables } \\
\text { are defined in Table } 1 \text {. } \\
{ }^{c} \text { All p-values on coefficients are based on one-tailed t-tests, with the exception of the intercept and SIZE, which are } \\
\text { based on a two-tailed t-test. } \\
{ }^{d} \text { Model Chi-square is the statistic of a Log-likelihood ratio test (two-tailed). }\end{array}$} \\
\hline
\end{tabular}

The Predictive Ability of the Likelihood of Material Misstatement Model

To test the predictive ability of the model (3) of the likelihood of material misstatement, I use the observed logistic regression equation from Table 7:

$$
P(i, t)=1 /\left(1+e^{-Z}\right)
$$

where: 
$\mathrm{Z}_{\mathrm{i}}=-4.947+15.630$ ALLOW $_{\mathrm{t}}+4.619$ OTHERLIAB $_{\mathrm{t}}+1.216$ NONOPER $_{\mathrm{t}}+45.306$ AQUIRE $_{\mathrm{t}}+1.807$

GROWTH $_{t}+7.557$ OTHASSET $_{t}+4.468$ DEPRATE $_{t}+6.281$ RESEARCH $_{t}-0.039$ EPSCHG $_{t}-02.47$

SIZE $_{\mathrm{t}}$

The predicted dependent variable, the probability of material misstatement for firm $i$, is computed using the actual material misstatement indicators for each organization in the initial sample. The resulting probabilities are used to predict which firms have a high likelihood of material misstatement. Jones (1987) suggests adjusting the cutoff probability for classifying firms in two ways. First, I incorporate the prior probability of material misstatement, and second, I include the cost of misclassification.

Using logit, the proportion of firms with a high likelihood of material misstatement (i.e., those with significant accruals estimation errors) in the sample must be the same as the proportion in the population to account for the prior probability of material misstatement. If the proportion is not the same, then the constant must be adjusted (Madala, 1991). This is more of a problem when a paired sample method is used, which is not the case here. Since I do not know the proportion of firms with a high likelihood of material misstatement in the population of all firms, I assume that the proportion in the sample is an unbiased estimator of the proportion in the population. Since $5.8 \%$ of the organizations in the sample have significant accruals estimations errors, I assume that the prior probability of material misstatement is 0.058. I evaluated the sensitivity of the model to other specifications of the prior probability of material misstatement by using prior probabilities of $0.01,0.10$ and 0.15 . These specifications did not alter the results significantly, and the results are not reported.

The ratio of the cost of type I errors (incorrectly classifying those with a high likelihood of material misstatement as having a low likelihood) to type II errors (incorrectly classifying organizations that have a low likelihood of material misstatement as having a high likelihood) also must be determined. The particular cost function is difficult to ascertain and will depend on the user of the information. For example, a creditor may want to minimize loan losses (and thus type I errors); however, he or she will suffer an opportunity cost (type II error) if the loan is granted to another borrower at a lower rate. In most cases, the cost of a type II error is likely to be much smaller that the Type I error rate. Thus, I incorporate several relative cost ratios (and cutoff probabilities) into my analysis. Specifically, I include the ratio of the relative costs of type I to type II errors of 1:1, 10:1, 20:1, 30:1, 40:1, 60:1, and 100:1 (Beneish 1999).

The results of using the logit model to classify firms with a high likelihood of material misstatement from those that have a low likelihood are included in Table 8 for the initial sample and the holdout sample. A firm with a probability of material misstatement below (above) the cutoff probability are predicted to have a low (high) likelihood of material misstatement.

TABLE 8

EXPECTED COST OF MISCLASSIFICATION (ECM) OF THE MATERIAL MISSTATEMENT MODEL

Panel A: Estimation Sample

\begin{tabular}{|l|l|l|l|l|l|l|l|}
\hline & \multicolumn{6}{l}{ Cost of Type I to Type II Error } \\
\hline & $\underline{1: 1}$ & $\underline{10: 1}$ & $\underline{20: 1}$ & $\underline{30: 1}$ & $\underline{40: 1}$ & $\underline{60: 1}$ & $100: 1$ \\
\hline Cutoff Prob. & 0.340 & 0.140 & 0.100 & 0.080 & 0.040 & 0.020 & 0.020 \\
\hline Type I Error & 0.343 & 0.259 & 0.235 & 0.223 & 0.177 & 0.115 & 0.115 \\
\hline Type II Error & 0.003 & 0.027 & 0.049 & 0.072 & 0.181 & 0.379 & 0.379 \\
\hline Overall Error & 0.021 & 0.036 & 0.052 & 0.070 & 0.155 & 0.312 & 0.312 \\
\hline ECM $_{\text {Model }}$ & 0.022 & 0.176 & 0.319 & 0.456 & 0.582 & 0.758 & 1.025 \\
\hline ECM $_{\text {Naive }}$ & 0.058 & 0.580 & 0.942 & 0.942 & 0.942 & 0.942 & 0.942 \\
\hline Relative Costs & 0.388 & 0.303 & 0.339 & 0.484 & 0.618 & 0.804 & 1.088 \\
\hline Overall Correct & 0.979 & 0.964 & 0.948 & 0.930 & 0.845 & 0.688 & 0.688 \\
\hline
\end{tabular}


Panel B: Holdout Sample

\begin{tabular}{|l|l|l|l|l|l|l|l|}
\hline & \multicolumn{9}{l}{ Cost of Type I to Type II Error } \\
\hline & $\underline{1: 1}$ & $\underline{10: 1}$ & $\underline{20: 1}$ & $\underline{30: 1}$ & $\underline{40: 1}$ & $\underline{60: 1}$ & $\underline{100: 1}$ \\
\hline Cutoff Prob. & 0.340 & 0.140 & 0.100 & 0.080 & 0.040 & 0.020 & 0.020 \\
\hline Type I Error & 0.393 & 0.327 & 0.288 & 0.260 & 0.205 & 0.127 & 0.127 \\
\hline Type II Error & 0.003 & 0.032 & 0.052 & 0.075 & 0.189 & 0.380 & 0.380 \\
\hline Overall Error & 0.021 & 0.041 & 0.056 & 0.074 & 0.164 & 0.317 & 0.317 \\
\hline ECM $_{\text {Model }}$ & 0.026 & 0.220 & 0.383 & 0.524 & 0.654 & 0.801 & 1.097 \\
\hline ECM $_{\text {Naive }}$ & 0.058 & 0.580 & 0.942 & 0.942 & 0.942 & 0.942 & 0.942 \\
\hline Relative Costs & 0.441 & 0.379 & 0.407 & 0.556 & 0.694 & 0.850 & 1.164 \\
\hline Overall Correct & 0.979 & 0.959 & 0.944 & 0.926 & 0.836 & 0.683 & 0.683 \\
\hline
\end{tabular}

The cutoff probabilities presented are those that minimize the expected cost of misclassification. Following Beneish (1999), the expected cost of misclassification, ECM, is computed as:

$$
\mathrm{ECM}_{\text {Model }}=\mathrm{P}(\mathrm{MM}) \mathrm{P}_{\mathrm{I}} \mathrm{C}_{\mathrm{I}}+[1-\mathrm{P}(\mathrm{MM})] \mathrm{P}_{\mathrm{II}} \mathrm{C}_{\mathrm{II}} \text {, }
$$

where $\mathrm{P}(\mathrm{MM})$ is the prior probability of material misstatement $(0.058), \mathrm{P}_{\mathrm{I}}$ and $\mathrm{P}_{\mathrm{II}}$ are the conditional probabilities of Type I and Type II errors, respectively, and $\mathrm{C}_{\mathrm{I}}$ and $\mathrm{C}_{\mathrm{II}}$ are the costs of Type I and type II errors, respectively.

The results indicate that the model can identify potential material misstatement at most ranges of the relative costs of type I to type II errors. The model correctly classifies ("Overall Correct") from $69 \%$ (at a $60: 1$ cost ratio) to $98 \%$ (at a 1:1 cost ratio) of the firms correctly. To test the usefulness of the model, I compare these results to a naïve strategy of classifying all organizations as having a high likelihood of material misstatement (having a low likelihood of material misstatement) when the ratio of relative costs is greater than (less than or equal to) the prior probability of material misstatement. The switch in strategy between classifying all organizations as having a low likelihood of material misstatement to classifying all of them as having a high likelihood of material misstatement occurs at relative cost ratios of approximately $17: 1(1 / 0.058)$, where 0.058 is the prior probability of material misstatement). If all organizations are classified as having a high likelihood of material misstatement (having a low likelihood of material misstatement), then the naïve strategy makes no type I (type II) errors. In this case, $\mathrm{P}_{\mathrm{I}}\left(\mathrm{P}_{\mathrm{II}}\right)$ is zero, and $\mathrm{P}_{\mathrm{II}}\left(\mathrm{P}_{\mathrm{I}}\right)$ is one. Thus, the expected cost of misclassification for the naïve strategy of classifying all firms having a low likelihood of material misstatement (having a high likelihood of material misstatement) reduces to $0.942 \mathrm{C}_{\mathrm{II}}\left(0.058 \mathrm{C}_{\mathrm{I}}\right)$ for the $\mathrm{ECM}_{\text {Naive }}$.

I report the ratio of the $\mathrm{ECM}$ for the model $\left(\mathrm{ECM}_{\text {Model }}\right)$ to the $\mathrm{ECM}$ for the naïve strategy $\left(\mathrm{ECM}_{\text {Naive }}\right)$ in Table 8, Panel A. A ratio of the relative costs of the model errors to a naïve strategy of less than one indicates that the model identifies potential material misstatement better than a naïve strategy. Except for the 100:1 cost ratio, the ECM Model is consistently less than or equal to a naïve strategy. These results provide evidence to suggest that the model of the likelihood of material misstatement is cost-effective in relation to a naïve strategy for most ranges of the relative costs of type I to type II errors. Tests on the holdout sample (in Panel B of Table 8) are very similar to the estimations sample and confirm these results.

\section{Applying the Model}

An example of applying the model follows. The example uses the indicators of material misstatement from an actual firm in the sample. The probability of material misstatement is:

$$
P(i, t)=1 /\left(1+e^{-Z}\right)
$$

where, from Table 7: 
$\mathrm{Z}_{\mathrm{i}}=-4.947+15.630$ ALLOW $_{\mathrm{t}}+4.619$ OTHERLIAB $_{\mathrm{t}}+1.216$ NONOPER $_{\mathrm{t}}+45.306$ AQUIRE $_{\mathrm{t}}+1.807$

GROWTH $_{t}+7.557$ OTHASSET $_{t}+4.468$ DEPRATE $_{t}+6.281$ RESEARCH $_{t}-0.039$ EPSCHG $_{t}-0.247$

SIZE $_{\mathrm{t}}$

Substituting the ratios from the example firm (in parentheses) for material misstatement gives:

$\mathrm{Z}_{\mathrm{i}}=-4.947+15.630(0.080)+4.619(0.010)+1.216(0.010)+45.306(0)+1.807(0.090)+7.557(0.010)$

$+4.468(0.080)+6.281(0)-0.039(0.190)-0.247(6.970)$

$\mathrm{Z}=-4.773$

$P(i, t)=1 /\left[1+e^{-(-4.773)}\right]=0.008$.

There is low likelihood that this firm has a material misstatement, since the computed probability $(0.008)$ is less than all ranges of the cutoff probabilities from Table 8. This firm actually has a low residual (not significantly different from zero) from the accruals estimation model. Thus, this firm was correctly classified as having a low likelihood of material misstatement.

This model is merely one possible way of measuring potential material misstatement. Caution should be used when applying this method and decisions should not be based on this information alone. Other financial and non-financial information should be considered when evaluating resource allocation and other similar decisions.

\section{CONCLUSIONS}

Over 20 years ago, Arthur Levitt, then chair of the SEC, foresaw the major accounting scandals through a decline in earnings quality, resulting from what he called "accounting illusions" (Levitt, 1998). He goes on to list several methods that firms employ to achieve such illusions. Based on these methods, I identify 10 financial indicators of material misstatement and determined that these indicators can distinguish firms with a high likelihood of material misstatement from those with a low likelihood. The financial indicators are intended to capture the financial environment that may lead to material misstatement. Firms with significant accrual estimation errors are considered to have a high likelihood of material misstatement. I use logistic regression to develop a model using financial indicators of material misstatement. The resultant model is used to determine the likelihood of material misstatement. Using a large sample across a 19 year period, the model is able to correctly classify up to $98 \%$ of firms as having either a high or a low potential for material misstatement.

This study provides a very practical method of computing the likelihood of material misstatement, including fraudulent financial reporting. The results are likely to be of interest to several parties, including investors, managers, board members, auditors, potential creditors, and regulators. As with any research, there are issues that provide a potential for future research. The sample includes US public firms not in the financial services sector. Future research could apply these results to the financial services sector and to firms in other countries. 


\section{REFERENCES}

American Institute of Certified Public Accountants (AICPA). (1972). Responsibilities and functions of the independent auditor. AU Section 110. New York: AICPA.

American Institute of Certified Public Accountants (AICPA). (2002). Consideration of fraud in a financial statement audit. AU Section 316. New York: AICPA.

Anabila, A. A. (2012). Value implications of the proportion of non-operating income. Journal of Accounting and Finance, 12(3), 54-70.

Barth, M. E., Cram, D. P., \& Nelson, K. K. (2001). Accruals and the prediction of future cash flows. The Accounting Review, 76(1), 27-58.

Beatty, A. L., Ke, B., \& Petroni, K. R. (2002). Earnings management to avoid earnings declines across pubicily and privately held banks. The Accounting Review, 77(3), 547-570

Beneish, M. (1997). Detecting GAAP violation: Implications for assessing earnings management among firms with extreme financial performance. Journal of Accounting and Public Policy, 16, 271-309.

Beneish, M. (1999). The detection of earnings manipulation. Financial Analysts Journal, (September/October), 24-36.

Collins, D. W., \& Kothari, S. P. (1989). An analysis of intertemporal and cross-sectional determinants of earnings response coefficients. Journal of Accounting \& Economics, 11(2), 143.

DeAngelo, L. E. (1986). Accounting numbers as market valuation substitutes: A study of management buyouts of public stockholders. The Accounting Review, 61(3), 400-420.

Dechow, P. M. (1994). Accounting earnings and cash flows as measures of firm performance: The role of accounting accruals. Journal of Accounting \& Economics, 18(1), 3-34.

Dechow, P., \& Dichev, I. (2002). The quality of accruals and earnings: The role of accrual estimation errors. The Accounting Review, 77(Supplement), 35-59.

Dechow, P., Kothari, S., \& Watts, R. (1998). The relation between earnings and cash flows. Journal of Accounting and Economics, 25(2), 133-168.

Dechow, P., \& Skinner, D. (2000). Earnings management: Reconciling the views of accounting academics, practitioners, and regulators. Accounting Horizons, 14(2), 235-250.

Dechow, P., Sloan, R., \& Sweeney, A. (1995). Detecting earnings manipulation. Accounting Review, 70 (April), 193-225.

Financial Accounting Standards Board (FASB). (2018). Conceptual framework for financial reporting. Statement of Financial Accounting Concepts No. 8, As Amended. Norwalk: FASB.

Gaynor, L. M., Kelton, A. S., Mercer, M., \& Yohn, T. L. (2016). Understanding the relation between financial reporting quality and audit quality. Auditing: A Journal of Practice \& Theory, 35(4), 122.

Guay, W. R., Kothari, S. P., \& Watts, R. L. (1996). A market-based evaluation of discretionary accrual models. Journal of Accounting Research, 34, 83-105.

Hand, J. R. M. (1989). Did firms undertake debt-equity swaps for an accounting paper profit or true financial gain? The Accounting Review, 64(4), 587-623.

Healy, P. (1985). The effect of bonus schemes on accounting decisions. Journal of Accounting and Economics, 7, 85-107.

Healy, P. M., \& Wahlen, J. M. (1999). A review of the earnings management literature and its implications for standard setting. Accounting Horizons, 13(4), 365-383.

Jones, F. (1987). Current techniques in bankruptcy prediction. Journal of Accounting Literature, (6), 131164.

Jones, J. (1991). Earnings management during import relief investigations. Journal of Accounting Research, 29, 2, (Autumn), 193-228.

Kormendi, R., \& Lipe, R. (1987). Earnings innovations, earnings persistence, and stock returns. The Journal of Business, 60(3), 323-346.

Levitt, A. (1998). The numbers game. New York Center for Law and Business. Retrieved December 9, 2018, from https://www.sec.gov/news/speech/speecharchive/1998/spch220.txt

Journal of Accounting and Finance Vol. 19(8) 2019187 
Lipe, R. (1990). The relation between stock returns and accounting earnings given alternative information. The Accounting Review, 65(1), 49-71.

Loebbecke, J., Eining, M., \& Willingham, J. (1989). Auditors' experience with material irregularities: frequency, nature, and detectability. Auditing: A Journal of Practice and Theory, 9, 1-28.

Maddala, G. (1991). A perspective on the use of limited-dependent and qualitative variables models in accounting research. Accounting Review, (October), 788-807.

McNichols, M. (2000). Research design issues in earnings management studies. Journal of Accounting and Public Policy, 19(4-5), 313-345.

McNichols, M., Wilson, G. P., \& DeAngelo, L. (1988). Evidence of earnings management from the provision for bad debts; discussion. Journal of Accounting Research, 26, 1-31.

Penman, S. H., \& Zhang, X. (2002). Accounting conservatism, the quality of earnings, and stock returns. Accounting Review, 77(2), 237-264.

Pinello, A. S. (2008). Investors' differential reaction to positive versus negative earnings surprises. Contemporary Accounting Research, 25(3), 8.

Ruch, G., \& Taylor, G. (2015). Accounting conservatism: A review of the literature. Journal of Accounting Literature, 34, 17-38.

Schipper, K., \& Vincent, L. (2003). Earnings quality. Accounting Horizons, 17, 97-110.

Trussel, J. (2003). Assessing Potential Accounting Manipulation: The Financial Characteristics of Charitable Organizations with Higher than Expected Program Spending Ratios. Nonprofit and Voluntary Sector Quarterly, 32 (December), 616-634. 